УДК 378.635.5:378.383

DOI:

Тетяна Сніца, кандидат педагогічних наук, викладач кафедри іноземних мов Національної академії Державної прикордонної служби України імені Богдана Хмельницького

\title{
ОСОБЛИВОСТІ НАВЧАННЯ ІНОЗЕМНОЇ МОВИ МАЙБУТНІХ ОФІЦЕРІВ-ПРИКОРДОННИКІВ
}

У статті проаналізовано роль та значення іноземних мов у процесі виконання офіцерамиприкордонниками професійних обов'язків в умовах ситуацій культурних перетинань. Авторкою проведено аналіз окремих теоретичних праць вітчизняних та зарубіжних дослідників щзодо необхідності оволодіння іноземними мовами майбутніми фахівцями різних спеціальностей. Розкрито сутність поняття "міжкультурна взаємодія”; обтрунтовано ефективність використання інтерактивних технологій та методів навчання з метою формування світогляду майбутніх офіuерів і розвитку навичок спілкування іноземною мовою.

Ключові слова: офіцер-прикордонник; професійна підготовка; професійна діяльність; міжкультурне середовище; взаємодія; іноземна мова.

תim. 7.

Tetiana Snitsa, Ph.D. (Pedagogy), Lecturer of the Foreign Languages Department Bohdan Khmelnytskyi National Academy of the State Border Guard Service of Ukraine

\section{PECULIARITIES OF FOREIGN LANGUAGE TRAINING TO FUTURE BORDER GUARD OFFICERS}

A qualitatively new level of relations between states and nations, as well as Ukraine's participation in world events, provide for changes in the system of training future border guard officers. The expansion of international cooperation, the organization of joint operational protection of the state border with EU member states require the personnel of the State Border Guard Service of Ukraine to know the cultural and national characteristics of other countries, the ability to communicate with foreign colleagues and citizens crossing the state border, to positively solve disputes, to be impartial and polite. Foreign language is one of the effective means to achieve these goals. The foreign language classes form the cadets' ability to abstract from their own real "role" in life and imagine the world from the perspective of a native speaker of another language and culture. To achieve productive learning, a foreign language instructor is expected to use a great deal of cultural knowledge, various forms and methods of teaching and upbringing.

Cadets learning a foreign language have to learn how to respond appropriately to their interlocutor's nonverbal messages. However, it is not necessary to imitate other people's behavior and communication patterns; they must be learned for successful performance of official duties at state border checkpoints. In the process of teaching a foreign language the individuality of languages and cultures should be highlighted. Knowledge of a foreign language is especially valuable if it is linked to cultural knowledge, knowledge about attitudes, perceptions, and stereotypes of people who speak the foreign language being studied.

The author has analyzed some theoretical works of Ukrainian and foreign researchers on the necessity of mastering foreign languages by future specialists. The definition of the concept of "intercultural interaction" is given; the effectiveness of using interactive technologies and teaching methods to form the worldview of future officers and develop communication skills in a foreign language is substantiated.

In the article there is given an example of the organization of the lecture course of the discipline "Linguistic and Cultural Studies", the analyses the effectiveness of the use of role-playing games for teaching a foreign language in a professional direction.

Keywords: border guard officer; professional training; professional activity; intercultural environment; interaction; foreign language.

П остановка проблеми у загальному вигляді. Інтеграційні процеси, які $\epsilon$ закономірним результатом невпинного розвитку людської цивілізації, невідворотно проникають в усі сфери життєдіяльності (політичну, економічну, соціальну, культурну) i приводять до розвитку контактів між країнами, організаціями, установами та окремими громадянами. $3 \mathrm{i}$ значним розширенням масштабів міжнародної взаємодії, зокрема туризму та торгівлі, з року в рік зростає кількість громадян, що перетинають кордони між країнами. Саме тут перетинаються представники різних країн, національностей, віросповідань, культур, мов тощо. І в цих умовах прикордонники здійснюють свою професійну діяльність. 3 огляду на це 
особливого значення набуває підготовка майбутніх фахівців прикордонної служби до діяльності в умовах полікультурного середовища, формування у них ціннісного ставлення до полікультурності, до розширення прикордонного та міжнародного співробітництва, формування і розвиток толерантності, здатності до міжнаціонального спілкування, комунікабельності, умінь знаходити спільну мову з партнером у комунікації, запобігати виникненню конфліктних ситуацій та залагоджувати їх, виховання поваги до співрозмовника, прагнення до співробітництва, взаємодії та взаєморозуміння. У рішеннях Колегії Державної прикордонної служби України (ДПСУ) неодноразово наголошувалося на необхідності активізації готовності прикордонників нести службу в умовах розширення прикордонного співробітництв відповідно до європейських стандартів. Для успішного виконання усіх поставлених задач сучасний офіцер-прикордонник повинен володіти як професійними знаннями, так і хоча б однією іноземною мовою.

Аналіз останніх досліджень і публікацій, у яких започатковано розв'язання даної проблеми. Результати аналізу наукових праць 3 питань професійної підготовки майбутніх офіцерівприкордонників свідчать, що науковці вивчали різні аспекти означеної проблеми. Зокрема, обгрунтування сучасних вимог до професійної підготовки офіцерського складу знаходимо у працях I. Блощинського, О. Войцехівського, Ю. Дем’янюка, О. Діденка, Є. Потапчука. Питання іншомовної професійної підготовки курсантів Національної академії Державної прикордонної служби України імені Богдана Хмельницького (НАДПСУ) були предметом наукового дослідження І. Блощинського, Т. Ваколюк, В. Мичковської, І. Сусліної, Л. Якубовської та ін.; Н. Берестецька досліджувала особливості підготовки майбутніх офіцерів-прикордонників до професійного спілкування у процесі навчання гуманітарних дисциплін, В. Назаренко - психологічні умови розвитку комунікативної компетентності керівників Державної прикордонної служби (ДПС) України, I. Балицький - специфіку професійної культури персоналу ДПС, що здійснює прикордонний контроль у пунктах пропуску на шляхах міжнародних сполучень. Міжкультурну компетентність як інтегративну характеристику випускника закладу вищої освіти (ЗВО) вивчали Н. Воронкова, I. Миронова, Я. Садчикова; проблеми навчання міжкультурного спілкування - Н. Бориско, А. Гордєєва, О. Красковська, Ю. Пассов та ін.

Формування мети статті. 3 огляду на вищезазначене метою статті є виявлення впливу знання іноземних мов на ефективність виконання професійних обов'язків офіцерами-прикордонниками у ситуаціях культурних перетинань.

Аналіз наукових робіт дає підставу зробити висновок, що, незважаючи на значну кількість досліджень 3 питань іншомовної підготовки майбутніх фахівців, проблема залишається актуальною і потребує подальшого вивчення, особливо стосовно мовної підготовки майбутніх офіцерів-прикордонників.

Виклад основного матеріалу дослідження. На необхідність підвищення якості професійної підготовки особового складу Державної прикордонної служби України впливає прагнення України до виконання вимог Угоди про асоціацію з Свропейським Союзом, необхідність підготовки прикордонників за гармонізованими стандартами європейських прикордонних відомств, посилення співпраці $з$ країнами НАТО з метою створення ефективної системи попередження та протидії загрозам національній безпеці [1].

Професійне становлення майбутнього офіцераприкордонника забезпечується злагодженою роботою усього колективу НАДПСУ - ректорату, керівників структурних підрозділів, викладачів. Факультети й кафедри НАДПСУ на основі рішень управлінської ланки забезпечують підготовку й відповідність професійно-важливих якостей випускників, закладених у нормативних та розроблених у вищих військових навчальних закладах (ВВНЗ) документах: кваліфікаційних характеристиках, навчальних планах і програмах спеціальностей, планах спільних науководослідницьких робіт ВВНЗ й замовника [3]. Досвідчений науково-педагогічний склад кафедр тактики прикордонної служби, прикордонного контролю, загальновійськових дисциплін докладає максимум зусиль, щоб кордони держави охороняли висококваліфіковані офіцери, віддані народу України та Конституції.

Вагомий внесок у становлення молодих фахівців робить кафедра іноземних мов. Враховуючи розширення міжнародних зв'язків і співробітництва у контексті боротьби 3 транснаціональною (транскордонною) злочинністю та тероризмом, англійська мова набуває статусу "lingua franca" (функціональний тип мови, що використовується для спілкування між носіями різних мов в умовах обмежених соціальних контактів). 3 огляду на це однією з основних вимог до поточної підготовки персоналу є підвищення рівня іншомовної комунікативної компетентності [2].

I. Ставицька визначає іншомовну комунікативну компетентність як складову професійної 


\section{ОСОБЛИВОСТІНАВЧАННЯ ІНОЗЕМНОӤ МОВИ МАЙБУТНІХ ОФІЦЕРІВ-ПРИКОРДОННИКІВ}

компетентності особистості, яка характеризується сукупністю знань, умінь і навичок, готовністю брати участь у комунікації з представниками інших лінгвоетнокультур. На думку дослідниці, слід узяти до уваги те, що навченість іноземної мови $є$ лише елементом комунікативної компетентності. Важливо не лише практично володіти мовою, а й розвивати інший образ свідомості, бути готовим сприйняти і зрозуміти соціокультурний портрет країни, мова якої вивчається, носіїв цієї мови, мовний такт і соціокультурну ввічливість. Саме тому вивчення іноземних мов на сучасному етапі набуває особливого значення та вимагає осучасненого підходу, оскільки сьогодні акцент необхідно робити на розвиток навичок міжкультурної взаємодії [6].

Ми визначаємо міжкультурну взаємодію як спілкування двох чи більше людей, спрямоване на пізнання один одного.

На переконання Е. Курбан і М. Кривошликової, міжкультурна взаємодія передбачає виникнення соціокультурного феномену, який також називають міжкультурним феноменом або міжкультурним діалогом, що розгортається в умовах взаємодії між країнами, народами та етносами, сприяє побудові цілої системи полікультурних контактів, підкреслює тяжіння самобутніх культур до чужорідних цінностей і зразків [5].

Готовність до міжкультурної комунікації дослідниця Г. Захарова розглядає як суттєвий аспект особистісної готовності молодої людини до повноцінної соціальної взаємодії, а отже, поряд 3 вирішенням завдань навчального характеру ЗВО повинен створити умови для розвитку особистості студентів, у тому числі - для формування готовності до міжкультурної взаємодії як надважливого фактора їх повноцінної самореалізації та самореалізації у суспільстві [4, 3-4].

Кожне заняття 3 іноземної мови - це перехрестя культур, це практика міжкультурної комунікації, оскільки кожне іноземне слово відображає іноземний світ та іноземну культуру: за кожним словом стоїть зумовлене національною свідомістю уявлення про світ.

3 метою формування навичок міжкультурної взаємодії на заняттях з іноземної мови в академії ДПСУ використовуються інтерактивні технології навчання. Серед найпоширеніших різновидів інтерактивних технологій ми називаємо проблемну лекцію, яка активізує пізнавальну активність курсантів, залучає їх до пошуку додаткової інформації, проведення самостійних дослідів. У курсантів, що навчаються за напрямом підготовки “Філологія”, є декілька лекційних курсів іноземною мовою - “Історія англійської мови”, “Лінгвокраїнознавство”, “Лексикологія", “Стилістика".

Великий освітній потенціал для курсантів має навчальна дисципліна “Лінгвокраїнознавство”, яка дає можливість пізнавати світ, використовуючи знання іноземної мови. У навчально-методичному забезпеченні цієї дисципліни є чимало культурокраїнознавчого матеріалу, який ознайомлює курсантів 3 особливостями поведінки та світосприйняття різних націй та народів. Окрім історико-географічних аспектів, курсанти вивчають традиції, звичаї та побут. Багато завдань курсанти отримують для самостійного опрацювання. Так, до прикладу, вивчаючи тему “Свята і традиції”, курсанти можуть підготувати інформацію про значимість, сутність та історичне походження свят не лише в англомовних, а й у країнах Сходу, Африки та Свропи. Використовуючи Інтернет, можна підготувати презентації у Power Point про те, як люди готуються до свят, що їдять і що п’ють, як зустрічають гостей, які готують подарунки. Після кожної презентації доречно організувати обговорення, під час якого курсанти можуть ставити запитання доповідачам, у представленій інформації про зарубіжні особливості шукати спільне та відмінне 3 українським. Ефективними будуть також завдання на формування навичок говоріння іноземною мовою на основі лінгвокраїнознавчого матеріалу:

- make up conversations with your group mates discussing the suggested questions about culture (the list of questions is ready);

- practice dialogues with different partners;

- express your attitude to the following idea "People should adapt to the customs and culture of the country they are visiting".

Отримання та обговорення інформації іноземною мовою дає можливість курсантам абстрагуватися від рідної мови і культури, зануритися у життя іншої країни і пізнати його.

Широко використовується на заняттях 3 іноземної рольова гра - інтерактивний метод, який дає змогу навчатися на власному досвіду шляхом спеціально організованого та керованого проживання життєвої або професійної ситуації, тематику яких можуть пропонувати курсанти. Проведення рольових ігор іноземними мовами допомагає курсантам 3 часом навчитися організовувати виважене обговорення, знаходити компроміс у неоднозначних ситуаціях, йти на поступки співрозмовникам, що має велике значення для офіцерів-прикордонників під час виконання службових завдань професійного спрямування. 
Під час рольової гри курсанти отримують досвід спілкування з іншими людьми, вчаться іноземною мовою правильно оформлювати висловлювання, звертання до учасників комунікації, використовувати невербальні засоби спілкування. Першими зустрічаючи гостей України на кордоні, прикордонники повинні демонструвати повагу до них та уміння правильно звертатися, тобто використовувати слова-індекси (a gentleman, a woman, professor, student etc.) та слова-регулятиви: віку.

Madam ['mжd.Ym] - до дорослої жінки.

$\boldsymbol{M r}$ ['mjs.tYr] - до будь-якого чоловіка чи хлопчика.

Mrs ['mjsjz] - до заміжньої жінки

Miss [mjs] - до незаміжньої жінки

$\boldsymbol{M s}$ [miz] - до жінки, не акцентуючи увагу на їі сімейному стані.

Окрім того, продуктивним є і сам процес підготовки до рольової гри, адже курсанти часто самостійно обирають тематику, розподіляють ролі, визначають комунікативні стратегії. Ці питання є дискурсивними i, як показує практичний досвід, спершу - доволі спірними і такими, що викликають агресивну дискусію. У таких випадках важлива партнерська роль викладача залагодити конфлікт, спрямувати обговорення у спокійне русло, не нав'язуючи курсантам своїх поглядів та думок. Необхідно пам'ятати, що викладач, крім усього, є єдиним носієм іншої мови i, відповідно, культури. Це покладає на нього значну відповідальність, оскільки саме він $є$ так званим “передавачем" культури іншої країни і багато чого курсанти сприймають саме через призму бачення цього їхнім викладачем. Гарною підмогою тут можуть бути автентичні фільми іноземною мовою, відеофрагменти, пісні, газети чи журнали. У наш час отримати усе це не $\epsilon$ проблемою.

Не варто також відмовлятися від особистого досвіду курсантів, адже багато з них уже встигли побувати за кордоном і хоча б трохи ознайомитися iз тамтешнім життям.

Як справедливо зазначає С. Тер-Мінасова, вивчення мови останнім часом стало більш функціональним. Людей не цікавлять ні теорія, ні історія мови, іноземна мова їм потрібна винятково для використання у різних сферах життя суспільства як засобу реального спілкування 3 людьми з інших країн [7]. Виконуючи вправи, читаючи тексти, розігруючи діалоги, курсанти також навчаються таких необхідних у спілкуванні речей, як непорушення особистого простору співрозмовника, регулювання гучності голосу, швидкості мовлення уміння оминати неприємні або табу теми.

Загалом, рольові ігри рекомендується використовувати як форму навчання та контролю задля активізації розумової діяльності, підвищення культури спілкування, тренування непідготовлених реплік іноземною мовою. Цікавими для курсантів $\epsilon$ такі теми ігор, як “Інцидент на пункті пропуску N”, “Зустріч іноземної делегації”, “Затримання нелегальних мігрантів”, “Огляд транспортного засобу на кордоні з країною X” та інші.

При обговоренні необхідно використовувати як діалогічні, так і монологічні форми висловлювання - це сприятиме формуванню у курсантів навичок міжкультурного спілкування. Уміння правильно організувати діалогічне спілкування допоможе учасникам інтеракції зрозуміти своє місце в обговоренні, зробити висновки про партнера по комунікації, бути більш відкритим та побачити себе очима співрозмовника.

Висновки 3 даного дослідження та перспективи подальших розвідок у даному напрямку. Навчання іноземної мови на сьогоднішньому етапі розвитку суспільства $\epsilon$ складним явищем. Для того, щоб рівень знань іноземної мови курсантів відповідав вимогам професійної практики, важливо охопити такі розділи - тематична лексика, необхідна умова успішної комунікації, знання відповідних граматичних правил, уміння та навички спілкування іноземною мовою, невербальні особливості спілкування іноземною мовою, особливості досліджуваної культури іншого народу, включаючи країнознавство і культуру повсякденного спілкування, порівняння 3 відповідними особливостями рідної культури. Великий потенціал має ознайомлення майбутніх офіцерів-прикордонників з пара вербальними i екстралінгвістичними засобами спілкування у професійних ситуаціях культурних перетинань.

\section{ЛIТЕРАТУРА}

1. Balendr A., Komarnytska O., Islamova, O., Khamaziuk O., Lusan P., \& Biliavets A. Online learning facilitation in border guards' foreign language training. Laplage in Journal, 7(2), 2021. https:// doi.org/10.24115/S2446-6220202172743 pp.336-345.

2. Блощинський I. Характеристика курсу дистанційного навчання англійської мови для персоналу державної прикордонної служби України. Вісник Національної академіі Державної прикордонної служби України. Серія Педагогічні науки. Хмельницький, 2016, Вип. 2,URL: file:///C:/Documents $\% 20$ and\%20Settings/ 
Администратор/Мои\%20документы / Vnadped 2016_2_3.pdf

3. Войцехівський О. Особливості підготовки майбутніх офіцерів-прикордонників до професійної діяльності в пунктах пропуску через державний кордон. Дрогобич. Молодь і ринок. №2 (73). 2011. С. $135-140$.

4. Захарова Г. В. Формирование готовности к межкультурной коммуникации у студентов вуза : автореф. дис...канд. пед.наук: 13.00.01. Общая педагогика, история педагогики и образования. Нижний Новгород, 2009. 164c.

5. Курбан Е., Кривошлыкова М. Межкультурное взаимодействие и межкультурная коммуникация: к определению аспектов. Социим и власть. 2013. № 1 (39). URL: https:// https://cyberleninka.ru/article/ n/mezhkulturnoe-vzaimodeystvie-i-mezhkulturnayakommunikatsiya-k-opredeleniyu-aspektov

6. Ставицька I. В. Іншомовна компетентність : місце дефініції у термінологічному полі сучасних наукових суджень. Педагогічні науки: теорія, історія, інноваиійні технологї. Суми. 2013. № 4 (30). С. 280-286.

7. Тер-Мінасова С. Язык и межкультурная коммуникация. Москва, 2000. С. 146.

\section{REFERENCES}

1. Balendr, A., Komarnytska, O., Islamova, O., Khamaziuk, O., Lusan, P., \& Biliavets, A. (2021). Online learning facilitation in border guards' foreign language training. Laplage in Journal,7(2), pp.336345. https://doi.org/10.24115/S2446-6220202172743 [in English].

2. Bloshchynskyi, I. (2016). Kharakterystyka kursu dystantsiinoho navchannia anhliiskoi movy dlia personalu derzhavnoi prykordonnoi sluzhby Ukrainy [Characteristics of the distance learning English course for the personnel of the State Border Guard Service of Ukraine]. Bulletin of the National Academy of the State Border Guard Service of
Ukraine. Series Pedagogical Sciences. Khmelnytskyi, vol. 2. Available at: file://C:/ Documents\%20and\%20Settings/Администратор/ Мои\%20документы/Vnadped_2016_2_3.pdf[in Ukrainian].

3. Voitsekhivskyi, O. (2011). Osoblyvosti pidhotovky maibutnikh ofitseriv-prykordonnykiv do profesiinoi diialnosti $\mathrm{v}$ punktakh propusku cherez derzhavnyi kordon [Peculiarities of preparation of future border guard officers for professional activity at state border checkpoints]. Youth \& market. Drohobych, Vol. 2 (73). pp. 135-140. [in Ukrainian].

4. Zaharova, G. V. (2009). Formirovanie gotovnosti k mezhkulturnoj kommunikacii u studentov vuza [Formation of readiness for intercultural communication to university students]. Extended abstract of candidate's thesis. General Pedagogy, History of Pedagogy and Education. Nizhnij Novgorod, 164 p. [in Russian].

5. Kurban, E. \& Krivoshlykova, M. (2013). Mezhkulturnoe vzaimodejstvie i mezhkulturnaja kommunikacija: k opredeleniju aspektov [Intercultural Interaction and Intercultural Communication: Toward a Definition of Aspects]. Society and Power. No. 1 (39). Available at: https:// https://cyberleninka.ru/ article/n/mezhkulturnoe-vzaimodeystvie-imezhkulturnaya-kommunikatsiya-k-opredeleniyuaspektov [in Russian].

6. Stavytska, I. V. (2013). Inshomovna kompetentnist : mistse definitsii u terminolohichnomu poli suchasnykh naukovykh sudzhen [Foreign Language Competence: The Place of Definition in the Terminological Field of Modern Scientific Judgment]. Pedagogical sciences: theory, history, and innovative technologies. Sumy. No. 4 (30). pp. 280-286. [in Ukrainian].

7. Ter-Minasova, S. (2000). Jazyk i mezhkulturnaja kommunikacija [Language and Intercultural Communication]. Word. Moscow, p. 146. [in Russian].

Стаття надійшла до редакції 29.09.2021

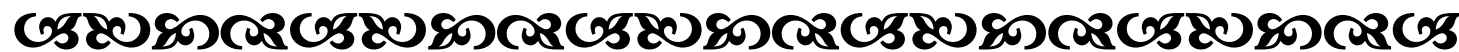

“Сеқрет майстерності в тому, що секрету немає, є просто-напросто талант”. Ірина Вільде

украйнська письменниия

“Сильні життєві потрясіння зиіляють від дрібних страхів”.

Оноре де Бальзак франиузький романіст і драматург

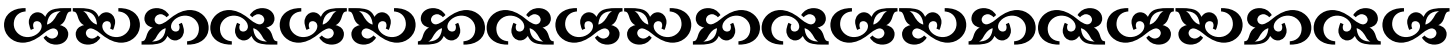

